\title{
Biopsy Site
}

National Cancer Institute

\section{Source}

National Cancer Institute. Biopsy Site. NCI Thesaurus. Code C77677.

The anatomic site targeted for a biopsy procedure. 